6. Шестопал А. В. Развитие информационного общества и контуры нового мирового порядка. Рационализм и культура на пороге третьего тысячелетия: материалы третьего российского философского конгресса (16-20 сентября 2002 г.). В 3 т. Т. 2: История древней и средневековой философии, история философии Нового и Новейшего времени, Русская философия, философия Востока, философия культуры, этика, эстетика. Коллоквиумы. Круглые столы. Ростов-на-Дону. 2002. С. 329-330.

7. Яскевич С. Социальная коммуникация как наука и специальность: становление, динамика, статус. Философия и социальные науки. 2016. № 3. С. 38-44.

\title{
References
}

1. Volkova, A. (2019). Significance of intercultural communications in the field of advertising and marketing: Russia and the United Kingdom. Retrieved from https://aeterna-ufa.ru/sbornik/SB-01. pdf\#page $=39$

2. Ivanov, D.V. (2002). The virtualization imperative. Modern theories of social change. Saint-Petersburg: Saint-Petersburg State Univerity [in Russian].

3. Kulikova, L.V. (2004). Intercultural communication: theoretical and applied aspects. On the material of Russian and German linguocultures: monograph. Krasnoyarsk: Editorial and publishing department of KSPU [in Russian].

4. Kuper, I.R. (2019) Hypertext as a way of communication. Retrieved from http://www.socio.ru/ bull/18. htm

5. Hitrov, A.V. (2008). Blog as a phenomenon of culture. Moscow: MSU [in Russian].

6. Shestopal, A.V. (2002). The development of the information society and the contours of the new world order. Rationalism and culture on the threshold of the third millennium: materials of the Third Russian Philosophical Congress (September 16-20, 2002). In 3 volumes. Vol. 2: The history of ancient and medieval philosophy, the history of the philosophy of New and Modern times, Russian philosophy, philosophy of the East, philosophy of culture, ethics, aesthetics. Colloquiums. Round tables. Rostov-on-Don [in Russian].

7. Yaskevych, S. (2016). Social communication as a science and specialty: formation, dynamics, status. Phylosophy and social sciences, № 3 [in Russian].

УДК 070:574(075.8)

Kynderevych Olena,

Ph.D. in Philosophy, associate professor, Associate professor of the Department of Philosophy, Kyiv National University of Culture and Arts 1.kunderevich@gmail.com orcid.org/ 0000-0001-7248-5033

\section{THE PROFESSIONAL STANDARDS AND SOCIAL RESPONSIBILITY IN THE FIELD OF THE PR-ACTIVITIES}

Purpose of the Article. The purposes of the article are to consider the ideas of the evolution, to study the sphere of professional activity and the model of the practice and ethical aspects of the public relations. In addition, we are aimed at the analysis of the mechanisms of the implementation of social responsibility and the establishment of professional standards in the field of PR-activities. Methodology. The methodology of the research is based on the general scientific and special methods of the cognition. They are an analysis, a synthesis, a logical method and a method of generalization. Scientific Novelty. The scientific novelty of the research consists in the introduction of the statement that the public relations technologies represent a universal «toolkit» for working with a free man. The presence of public relations technologies can be identified 
by the social links that can exist in the stable market economy, protected by the laws of the state. Conclusions. The analysis of the functions of public relations in the field of business shows that in general the process of organizing work in this area must consist of two main components: the development of a business structure's strategy of public activity and its implementation. The Corporate Social Responsibility Programs should be considered as part of the corporate communications strategy that meets the tasks of public relations, which have to take into account the interests of both partners. The social responsibility policy expands the range of the business structure's communication capabilities of the public relations by introducing new tools of the interactions.

Key words: social technologies, technologies of «public relations», social responsibility, professional standards, ethics of the PR, public opinion.

Кундеревич Олена Вікторівна, кандидат філософських наук, доцент, доцент кафедри філософії Київського національного університету культури і мистецтв

\title{
ПРОФЕСІЙНІ СТАНДАРТИ ТА СОЦІАЛЬНА ВІДПОВІДАЛЬНІСТЬ В СФЕРI PR-ДІЯЛЬНОСТІ
}

\begin{abstract}
Метою роботи є аналіз функцій соціальних технологій, з 'ясування значення механізмів реалізаиіі соиіальної відповідальності та становлення професійних стандартів в сфері PR-діяльності. Методологія дослідження базується на застосуванні загальнонаукових та спеціальних методів пізнання, зокрема: аналізу, синтезу, логічного методу та методу узагальнень. Наукова новизна полягає у запровадженні твердження про те, щцо технологї паблік рилейшнз уявляють собою універсальний , ,інструментарій” роботи з вільною людиною. Наявність же технологій паблік рилейшнз може бути ідентифіковано з наявністю зрілих суспільних зв 'язків, які можуть існувати в умовах досить стабільної ринкової економіки, що захищена законами держави. Висновки. Аналіз функиій паблік рилейшнз у сфері бізнесу показує, щзо в найзагальнішому вигляді прочес організації роботи у цій сфері має складатися $з$ двохосновних компонентів: по-перше, розроблення стратегії громадської діяльності бізнес-структури; по-друге, реалізачія иієї стратегії. Програми корпоративної соиіальної відповідальності мають бути розглянуті як складові комунікаиійної стратегї̈ корпорації, щзо відповідають завданням зв'язків з громадськістю, тобто побудові відносин між корпорачією і громадськістю, які враховують інтереси обох сторін. Політика сочіальної відповідальності розширює спектр комунікаційних можливостей зв'язків з громадськістю бізнес-структури, привносячи нові інструменти взаємодії.
\end{abstract}

Ключові слова: сочіальні технології, технології «паблік рилейшнз», сочіальна відповідальність, професійні стандарти, етика PR, громадська думка.

Кундеревич Елена Викторовна, кандидат философских наук, доцент, доцент кафедры философии

Киевского национального университета культуры и искусств

\section{ПРОФЕССИОНАЛЬНЫЕ СТАНДАРТЫ И СОЦИАЛЬНАЯ ОТВЕТСТВЕННОСТЬ В СФЕРЕ PR-ДЕЯТЕЛЬНОСТИ}

Целью работы является анализ функций социальных технологий, выяснение значения механизмов реализации социальной ответственности и становления профессиональных стандартов в сфере PRдеятельности. Методология исследования базируется на применении общенаучных и спещиальных методов познания, в частности: анализа, синтеза, логического метода и метода обобщений. Научная новизна заключается в обосновании утверждения о том, что технологии паблик рилейшнз представляют собой универсальный «инструментарий» работы по свободным человеком. Наличие же технологий паблик рилейшнз может быть идентифицировано с наличием зрельх общественных связей, которые могут сущесттвовать в условиях достаточно стабильной рыночной экономики, защищенной 
законами государства. Выводы. Анализ функиий паблик рилейшнз в сфере бизнеса показывает, что в самом общем виде процесс организации работы в этой сфере должен состоять из двух основных компонентов: во-первых, разработка стратегии общественной деятельности бизнес - структуры; во-вторых, реализация этой стратегии. Программы корпоративной социальной ответственности долюжны быть рассмотрены как составляющие коммуникационной стратегии корпорации, соответствуюших задачам связей с общественностью, то есть построении отномений между корпорацией и общественностью, которые учитывают интересы обеих сторон. Политика сочиальной ответственности расширяет спектр коммуникационных возможностей связей с общественностью бизнес - структуры, привнося новые инструменты взаимодействия.

Ключевые слова: сочиальные технологии, технологии «паблик рилейшнз», социальная ответственность, профессиональные стандарты, этика $P R$, общественное мнение.

The actuality of Research. The professional field of public relations activities is constantly expanding and developing. Some aspects of it go to the background, whereas the others become the priorities, responding to the challenges of society. Due to such processes, the issue of the definition of the profession of public relations is still relevant. Its boundaries are mobile and its concept continues to be clarified and specified.

Analysis of Researches and Publications. In economics, the principle of corporate responsibility for social development was first formulated by H.-R. Bowen in his book «Social Responsibilities of the Businessman» (1953). The issues of the interaction between business and society are analyzed in the works of the following scientists: P. Kotler, P. Drucker, R.-E. Freeman, J. Simon, B. Thompson, M. Mescon, A. Carroll, and others. In addition, we can find deep research of the concepts of social responsibility, as well as the attempts to systematize them in the works of A. Carroll, M. Van Marwijk, R. Steuer, et al.

The problem of forming a social partnership in Ukraine is highlighted by such theorists as D. Bogin, O. Grishnova, V. Gerasimchuk, V. Dovbnya, A. Kolot. However, the issues of social responsibility and ethics in public relations are little studied.

The purposes of the article are to consider the ideas of the evolution, to study the sphere of professional activity and the model of the practice and ethical aspects of the public relations. In addition, we are aimed at the analysis of the mechanisms of the implementation of social responsibility and the establishment of professional standards in the field of PR-activities.

Main part. The chosen theme is very important from a practical point of view. In mod- ern Ukraine, the field of public relations is being formed. So, it determines the need to improve the system of professional ethics and the implementation of foreign standards and experience in the national mentality. The term "social technology» is rooted in the general concept «technology», which first meaning is dealt with social knowledge. The main function of social technologies is to optimize the system of the social management of the expanding of social innovation. In general, social technologies exist in two forms. The first one is the structural element of any system that is technologically designed as a software product. The second form is the managerial activity, associated with the implementation of this software product. According to K. Mannheim: «Like any other technology, social technology is neither bad nor good. Everything depends on how the human mind and will use it. The modern social technologies, which develop without any control, often lead to dictatorship. If we control these technologies and make them serve for good goals, when the technologies do not dominate, they can be considered one of the most positive achievements of mankind» $»[1]$.

The social technologies are an important element of any cultural and civilization system. The technology of «Public relations» is one of the forms of the basic social technologies of the civilization of Modern. One of the main tasks of «Public relations» is to build an effective two-way communication of the subject of the public discourse with its focus public in a dialogue mode. S. Black defines the essence of public relations in the following way: «The basic philosophy of public relations is very simple. It comes from the fact that it is much easier to achieve success in the realization of goals with public support and 
understanding than in a situation of public opposition or indifference. The philosophy of public relations can be formulated in a few words. We are talking about reputation, perception, trust, confidence, harmony and a search for mutual understanding, which are based on truth and full awareness. This provision is not the complete definition of public relations, but we can see its necessary elements» [2].

We should begin the analysis of the development of the field of public relations technologies as a management system of public relations from the first decades of the twentieth century. Indeed, public relations technologies were the results of the industrial revolution, when monopolists felt the lack of management methods in the industrial sphere. The public relations technologies represent the universal «toolkit» for working with a free man. The presence of public relations technologies can be identified by the social links that can exist in the stable market economy, protected by the laws of the state.

The modern society determines the complication of the relations in the field of labor and the content of the work process, the growth of important criteria in the characterization of the labor collective and the quality of work. Due to the growth of the division, the new professions appear. In these conditions, it is necessary to create moral codes of labor collectives. The public relations are the young field of activity, especially for our country. So, it is not well-known and welldeveloped here. Recently, the relevance of the discussion of ethical issues in PR has increased. However, today there is no defined direction in the development of the PR-activities ethical aspects. This problem is open to broad discussion in society. For example, the discussion issues of the advertising and marketing communications are being solved within the professional ethics of the PR.

Determining public relations, many specialists underline its connections with the process of communication management. It includes the following functions: monitoring and influence on the public opinion; the information analysis and the management of the information flows; the organization; the determination of the strategy and the other functions. Thus, today the profession of the public relations can only be considered as the management function, related to the communication management between organizations and the public, in order to harmonize and optimize their social interaction. In this case, the PR-activity is a way of establishing and ensuring the mutual understanding, dialogue, cooperation among social actors in the democratic society. Whereas, we can meet the position that the public relations are only the communicative technology that allows us to speak and distribute everything in the society, which is profitable for the «owner», and to achieve its defined goals.

The idea of the public relations evolution as a sphere of professional activity gives us the models of PR-practices that are described in the works of J. Grunig and T. Hunt [3]. The first model is called the «press mediation» or «print campaign». The purpose of this activity is to promote and create pressure on public opinion by using any means to attract public attention. The second one is the historically-made model (the beginning of the twentieth century). It is primarily dealt with the informing society, creating a need for regular media work. In this case, the disseminated information must be accurate, truthful, and necessarily positive for the customer.

In the conditions of the virtualization of the society, public relations technologies appear as an instrument of the simulation of social interaction and social agreement. However, they continue to regulate relations and resolve the main contradictions and conflicts among society, state, business, mass culture, and the «mass personality» by the influence on their will, consciousness, behavior, value principles, etc. The blending of the methods of PR, propaganda, and advertising has nothing to do with the professional PR-activities.

If the professional technology separates from the content of the public relations as a strategy of trust and consensus, the profession separates from its ethical regulators. One of the main ethical dilemmas is the need to choose between the interests of the customer and the interests of society.

Thus, it is necessary to find a variant correlative to the requirements of the PR professional sphere as an area of the necessary and effective construction of a two-way symmetric link between the PR-firm (the information producer) and its environment (consumer information). An- 
alyzing this paradigm, we can study two possible conceptions - the communicative or normative paradigm of J. Habermas and the functional paradigm of N. Luhmann. The second one describes how the communicative systems work in connection with the general principle of the operation of open systems. The paradigm of J. Habermas responds to the urgent question of the professional in the field of PR: «how to organize the communication in order to get a fair rule». Both concepts enrich each other in the integrated sense of the process of establishing public relations. However, today the offered models of decisionmaking in the areas of "free professions» (they have the highest degree of conflict on the basis of the ethical conflicts) are oriented mainly on the communicative paradigm of J. Habermas, which takes into account deontology as well as the utilitarian aspects of possible decision-making in a conflict situation.

There are discussions between media representatives and PR-practitioners, dealt with the policy of the organizations. If they should be fully open to their public and the media. Journalists want the sincerity and full information, while the PR-specialists often feel they are not obliged to highlight the whole truth about their client organizations. This situation leads to disinformation and further misunderstandings. The essence of the problem is the difference between openness in organizations with the "symmetric» and «asymmetric» PR models. The organizations with a two-way symmetrical public relations model are constantly interacting with their consumers. The latter even take part in the dialogue as a partner. The symmetrical methods of PR mean the search and applying the tools to rule public opinion. Each of the PR models can be effective in terms of adequate using.

Many PR professionals support the idea of openness in communication with the public and the media, but their point of views differ. The openness can be selective (to show the public and the media only the selective information, by the organization. It is an asymmetric model), or full (openness of the organization for the dialogue with the public and mass media. It is a symmetrical one). The symmetrical and asymmetric external relations can be ethical. The PR-specialists cannot always highlight the issues, concern- ing the company's activities (symmetrical), but it is desirable to explain to the public why the company's plans should be kept in a secret. The asymmetric relationships can be ethical if the PR specialist reveals the motives of the asymmetric openness and selective secrecy.

Consequently, both symmetric and asymmetric external relations can be ethical if the employees of the organizations explain the intentions with of the made message. The international practice of identifying the best companies testifies that those companies, which act on the principles of ethics, are the most popular. They do in accordance with the principles of the socially responsibility, moral consensus among all elements of the internal structure and the external environment.

It should be noted that «social responsibility» does not mean the «collective responsibility». The responsibility is effective when it becomes an individual one. The implementation of social responsibility means the implementation of such a procedure, which will remind each representative of the authority about their personal responsibility before the public and require a permanent report on his activities. The responsibility opens up the space for creativity and self-development, as well as for society as a whole. In this sense, moral responsibility differs from the legal one, since it provides the opportunities to go beyond the limits of the specified by the law. To go beyond the limits of the laws is to implement their requirements as well as to improve them if they do not meet the requirements of the present. It is also necessary to remember that the specialists can act in the way they want, but they must be responsible for both success and failures.

The adherence to the rules, ethical behaviour and professionalism must be the key elements for the PR specialist. They are the basis of the establishment of professional standards. In the PR area, several codes regulate the ethical aspects of PR activities. We can list up the following: the Code of Professional Activities and Ethics, adopted by the International Association of the PR (IPRA) at its General Assembly in Venice in May 1961, the Athens Code, adopted in Athens by the General Assembly of the IPAA in May 1965 (its changes were implemented in April 1968), the European Code of the Profes- 
sional Behaviour in the field of PR, entitled «Lisbon Code», adopted in Lisbon on April 16, 1978, at the General Assembly of the European Confederation of PR (CEPR) and supplemented on May 13, 1989, the Code of the Professional Behaviour of the Institute of the PR, adopted in England at the annual session of the PR Institute on April 9, 1986, the Code of Professional Behaviour in Public Relations, adopted by the Ukrainian National League on Public Relations on March 12, 2005. Many professional organizations believe that the core tasks of ethics codes are the education and professional information, which are aimed to the formation of the standards of the behaviour that serves as a model for members of their professions. The International Association of Specialists in Business Communication (IAVS) supports this approach.

Conclusions. The analysis of the functions of public relations in the field of business shows that in general the process of organizing work in this area must consist of two main components: the development of a business structure's strategy of public activity and its implementation. The Corporate Social Responsibility Programs should be considered as part of the corporate communications strategy that meets the tasks of public relations, which have to take into account the in- terests of both partners. The social responsibility policy expands the range of the business structure's communication capabilities of the public relations by introducing new tools of the interactions.

The conflict between the ethics of the PR and the ethos of the PR is so deep. Today there are two areas that exist in parallel. This parallelism of the PR theory and practice damage the profession and its existence. «Despite the significant progress in the development of the public relations during the twentieth century, the public is not ready to recognize the right of the public relations to be called a real profession» [4].

All in all, the professional technology, divorced from the nature of public relations, as a strategy of trust and consensus, leads to the removal of the public relations from its ethical regulators. That is why the necessity of the selfregulation, self-control as well as the legislative regulation in modern Ukraine is crucial. The fact that many PR-specialists are oriented in their activities on but on the career growth illustrates the transitional stage in the development of the PR. This is a problem of the public sphere as well as the state: the maturity of market relations, the legislative framework, economic factors and the level of democratic processes.

\section{Список використаних джерел}

1. Маннгейм К. Диагноз нашего времени / Пер. с нем. Москва : Юрист, 1994. С. 417.

2. Black S. The essentials of public relations. London : Rogan page, 1993. P.11.

3. Grunig J., Hunt T. Managing Public Relations. N. Y. : Holt, Rinehart and Winston, 1984. 213 p.

4. Скотт М. Катлип, Аллен Х. Сентер, Глен М. Брум. Паблик рилейшнз: теория и практика. Москва : Вильямс, 2008. 640 c. C.214.

\section{References}

1. Mannheim, K. (1994). The Diagnosis of Our Time. Moscow: Yurist [in Russian].

2. Black, S. (1993). The Essentials of Public Relations. London: Rogan pag [in English].

3. Grunig, J. \& Hunt, T. (1984). Managing Public Relations. New York: Holt, Rinehart, and Winston [in English].

4. Scott M. Kathleen, Allen H. Center, Glen M. Broom. (2008). Public Relations: Theory and Practice. Moscow, Williams [in Russian]. 